Vol. 1 No. 2 September 2021 e-ISSN : 2797-3344 P-ISSN : 2797-3336

\title{
PENGEMBANGAN LKS BERBASIS MODEL DISCOVERY LEARNING PADA PEMBELAJARAN MATERI LENSA SISWA SMP NEGERI 4 BONTANG
}

\author{
WAHYUDI \\ SMP negeri 4 Bontang \\ e-mail: wahyudismpn4bontang@gmail.com
}

\begin{abstract}
ABSTRAK
Penelitian ini dilatarbelakangi oleh keberadaan guru IPA SMP negeri 4 Bontang yang belum mampu membuat lembar kegiatan siswa (LKS) yang baik dalam pembelajaran. Tujuan penelitian ini adalah untuk menghasilkan LKS berbasis discovery learning yang valid, praktis, efektif dan dapat meningkatkan hasil belajar siswa. Pengembangan LKS dalam penelitian ini mengikuti desain Kemp dan diujicobakan di kelas 8 SMPN 4 Bontang semester genap tahun ajaran 2013/2014. Desain dalam penelitian ini menggunakan One Group Pretest-Posttest Design. Pengumpulan data menggunakan metode observasi, tes, dan angket. Teknik analisis data menggunakan analisis deskriptif kuantitatif, dan kualitatif. Hasil penelitian ini menunjukkan: 1) LKS yang dikembangkan terbukti valid, praktis, dan efektif. Kefektifan LKS ditinjau dari (a) Hasil belajar siswa terlihat dari $N$-Gain dengan kategori tinggi, (b) Respon siswa terhadap penggunaan LKS sangat positif. Disimpulkan bahwa LKS berbasis model discovery learning yang dikembangkan valid, praktis dan efektif untuk meningkatkan hasil belajar.
\end{abstract}

Kata Kunci: Perangkat Pembelajaran, Discovery Learning, Lensa

\section{ABSTRACT}

This research is motivated by the existence of science teachers at SMP Negeri 4 Bontang who have not been able to make good student activity sheets (LKS) in learning. The purpose of this research is to produce discovery learning-based worksheets that are valid, practical, effective and can improve student learning outcomes. The development of worksheets in this study followed Kemp's design and was piloted in the 8th grade of SMPN 4 Bontang in the even semester of the 2013/2014 academic year. The design in this study used the One Group PretestPosttest Design. Collecting data using the method of observation, tests, and questionnaires. The data analysis technique used quantitative and qualitative descriptive analysis. The results of this study indicate: 1) The developed worksheets are proven to be valid, practical, and effective. The effectiveness of LKS in terms of (a) Student learning outcomes can be seen from the NGain with a high category, (b) Student responses to the use of LKS are very positive. It was concluded that the LKS based on the discovery learning model that was developed was valid, practical and effective to improve learning outcomes.

Keywords: Learning Devices, Discovery Learning, Lenses

\section{PENDAHULUAN}

Lembar kegiatan siswa (LKS) merupakan salah satu bahan ajar bagi siswa di kelas. Menurut Septantiningtyas (2021), LKS merupakan lembaran kerja yang memuat informasi dan serangkaian kegiatan yang terkait dengan apa yang sedang dipelajarinya. Penggunaan LKS untuk mempermudah meraih tujuan pembelajaran yang telah ditetapkan. Prastowo (2014), menjelaskan LKS merupakan alat bantu yang diberikan kepada siswa oleh seorang guru dalam pembelajaran, yang berfungsi sebagai petunjuk pelaksanaan pembelajaran, dan tugas yang harus diselesaikan oleh siswa yang mengacu pada satu kompetensi dasar. LKS menjadi bahan ajar yang mampu membantu siswa untuk belajar melalui usahanya sendiri.

Umumnya siswa memiliki karakter yang beragam, mereka dapat terbantu dengan adanya bahan ajar yang memadahi, karena bahan ajar dapat menuntun kegiatan belajar siswa (Lestari. 2013). Penggunaan LKS dalam pembelajaran dapat meningkatkan pemahaman siswa 


\section{Vol. 1 No. 2 September 2021 e-ISSN : 2797-3344 P-ISSN : 2797-3336}

terhadap konsep yang dipelajarinya, karena siswa terlibat secara langsung dalam pencarian konsep.

Adapun Model pembelajaran discovery learning adalah model pembelajaran penemuan, dimana siswa yang banyak menemukan konsep sendiri. Dalam proses belajaran mengajar siswa tidak hanya menunggu pengalaman dari dari guru. Peran guru hanya sebagai fasilitator di dalam kelas. Berdasarkan teori pembelajaran, model pembelajaran discovery learning merupakan model pembelajaran yang berpusat pada siswa (student centered), siswa dituntut aktif selama proses pembelajaran (Alfitry. 2020).

Penelitian semisal terkait penggunaan LKS atau LKPD dalam pembelajaran secara umum mampu meningkatkan hasil pembelajaran. Sebagaimana penelitian yang dilakukan oleh Ulfah (2013), mendapatkan hasil bahwa pengembangan LKS IPA berbasis word sguare tema pencemaran lingkungan layak dan efektif digunakan sebagai bahan ajar dalam pembelajaran IPA. Penelitian selanjutnya dilakukan oleh Damayanti (2013), terkait pengembangan lembar kerja siswa (LKS) dengan pendekatan inkuiri terbimbing menunjukan hasil dapat mengoptimalkan kemampuan berfikir siswa.

Namun fakta yang ditemui peneliti, khususnya di sekolah tempat peneliti mengajar, masih terdapat guru yang belum mampu membuat LKS yang baik. Bahkan guru mengajar tanpa menggunakan LKS sebagai bahan ajar untuk meningkatkan hasil belajar siswa. Begitu juga, metode mengajar yang digunakan masih monoton cenderung ceramah dan latihan soal. Kondisi pembelajaran yang demikian kurang efektif untuk mewujudkan tujuan pembelajaran.

Pengembangan LKS yang valid, praktis dan efektif, dipadu dengan model pembelajaran discovery learning dinyakini oleh peneliti merupakan model yang cocok untuk dapat menghantarkan tercapainya hasil pembelajaran materi lensa. Model discovery learning menekankan adanya eksperimen dalam pembelajarannya, yaitu metode pembelajaran yang memberikan pengalaman tersendiri bagi anak didik untuk terlibat langsung dengan kondisi lingkungan sekitar.

Pengembangan LKS berbasis model discovery learning memerlukan percobaanpercobaan yang memungkinkan anak didik merasa senang dengan nuansa pembelajaran yang dianggap menarik dan memberikan daya pikat yang cukup mengesankan. Keunggulan pembelajaran menggunakan model discovery learning pada siswa tidak hanya terletak pada ketrampilan dalam meneliti dan mencari pemecahan permasalahan. Lebih dari itu anak didik didorong mampu mengolah dan menggali informasi, serta mendapatkan data-data kongkret mengenai suatu hal yang berkaitan dengan strategi pembelajaran. Ketika para siswa mampu mengolah dan menggali informasi, serta data-data yang dianggap penting, maka secara tidak langsung mereka akan menemukan sesuatu yang baru (Takdir, 2012).

Adapun mengenai karakteristik bahan lensa, lensa adalah benda bening yang dibentuk sedemikian rupa sehingga dapat meneruskan hampir semua cahaya yang melaluinya. Jenis lensa ada dua macam yaitu lensa cembung (lensa positif) dan lensa cekung (lensa negatif). Masing-masing jenis lensa memiliki sifat dan ciri-ciri tersendiri dalam membiaskan cahaya, begitu juga pemanfaatannya bagi manusia.

Pembahasan tentang lensa tidak bisa dipisahkan dari sifat sinar cahaya. Perpaduan keduanya dalam konsep pembiasan akan sangat mudah dengan adanya alat lensa dan sumber sinar cahaya sehingga konsep, prinsip dan wujut lensa dapat difahami dengan jelas oleh siswa. Konsep pembiasan, titik fokus, bidang utama, kelengkungan lensa, prinsip pembentukan bayangan, sinar istimewa, dan sifat lensa cembung dan cekung dapat disajikan kepada siswa dengan memberikan pengalaman langsung pada siswa melalui LKS berbasis model discovery learning di laboratorium.

Berdasarkan uraian di atas, penelitian ini mengembangkan LKS berbasis model discovery learning untuk meningkatkan hasil belajar pada materi lensa. Pengembangan LKS berbasis model discovery learning di dalamnya berisi tujuan pembelajaran, ringkasan materi tentang lensa, prosedur kegiatan siswa mencari titik fokus lensa, sifat bayangan yang dihasilkan, dan bagian-bagian lensa dengan bantuan sinar. Dengan petunjuk yang telah 
ditentukan, siswa akan menemukan titik fokus lensa, sifat bayangan yang dihasilkan lensa, dan bagian bagian lensa.

Pengembangan LKS berbasis model discovery learning ini diharapkan dapat memudahkan guru dalam melakukan pembelajaran di kelas. Dengan menggunakan LKS yang telah dikembangkan diharapkan siswa dapat meraih konsep tentang materi lensa dengan baik. Hasil belajar yang ingin diraih dalam penggunaan LKS ini meliputi aspek kognitif, afektif, dan psikomotorik.

Penelitian pengembangan LKS sejenis untuk meningkatkan hasil belajar siswa belum pernah dilakukan di SMP negeri 4 Bontang. Kegiatan pembelajaran dalam penelitian ini akan menjadi hal baru bagi mereka dalam belajar materi lensa di kelas. Harapan peneliti, melalui kegiatan pembelajaran yang sesuai antara bahan ajar dan model dalam pembelajaran dapat meningkatkan hasil belajar IPA khususnya materi lensa.

Berdasarkan uraian di atas maka dapat dirumuskan masalah penelitian ini adalah bagaimanakah mengembangkan LKS yang valid, praktis dan efektif berbasis model discovery learning dapat meningkatkan hasil belajar materi lensa siswa kelas 8 SMP Negeri 4 Bontang?

\section{METODE PENELITIAN}

Penelitian ini merupakan jenis penelitian pengembangan. Peneliti mengembangkan bahan ajar berupa LKS yang valid, paktis, dan efektif berbasis model discovery learning. Untuk meningkatkan hasil belajar pada materi lensa. Subyek penelitiannya adalah siswa kelas 8 SMP negeri 4 kota Bontang. Pelaksanaan pada tanggal 9 - 17 Mei 2014. Jumlah siswa terbatas sebanyak 32 siswa. Prosedur penelitian ini dilaksanakan melalui dua tahap yaitu tahap pengembangan LKS dan ujicoba di kelas. Ujicoba 1 sebanyak 15 siswa yang disebut dengan ujicoba kecil. Sedangkan ujicoba 2 disebut uji coba besar pada 3 kelas replikasi. Masing-masing kelas terdiri 32 siswa yang homogen. Prosedur pengembangan bahan ajar LKS terdiri dari sembilan unsur proses perancangan, yang mengacu pada model pengembangan Kemp(1994). Model pengembangan tersebut terdiri atas: (1) Instructional Problems, (2) Learner Characteristics, (3) Task Analysis, (4) Instructional Objectives, (5) Content Sequencing, (6) Instructional Strategies, (7) Instructional Delivery, (8) Evaluation Instrumens, dan (9) Instructional Resources. Prosedural percobaan lensa yang tertuang dalam LKS sebagai panduan kegiatan siswa di laboratorium, sebagai berikut:

a. Prosedur menentukan sifat bayangan yang dibentuk oleh lensa cembung.

b. Prosedur menyelidiki sifat pembiasan cahaya pada lensa cekung.

c. Prosedur memanfaatkan lensa cekung pada penderita miopi.

Prosedur uji bahan ajar LKS salah satu kegiatannya adalah uji coba. Untuk mengamati data hasil penelitian yaitu hasil belajar siswa dengan menggunakan bahan ajar LKS berbasis model discovery learning. Rancangan uji coba dengan model one-group, Pre Test-Post Test Design. Variabel penelitian ini adalah; 1) kevalitan bahan ajar LKS model discovery learning, 2) keterbacaan bahan ajar LKS yang dikembangkan, 3) aktivitas siswa selama kegiatan belajar mengajar, 4) respon siswa setelah mengikuti proses pembelajaran, dan 5) hasil belajar siswa. Instrumen penelitian yang digunakan untuk pengumpul data sebagai berikut: 1) lembar validasi bahan ajar LKS, 2) lembar keterbacaan bahan ajar LKS. 3) lembar pengamatan keterlaksanaan bahan ajar LKS, 4) lembar pengamatan aktivitas siswa, 5) lembar tes hasil belajar siswa, dan 6) lembar angket respon siswa siswa terhadap model discovery learning. Untuk mengetahui apakah perbedaan hasil belajar yang diperoleh dari pengujian awal (pretest) dan pengujian akhir (posttest) merupakan efek dari pembelajaran yang dilakukan, perlu diketahui sensitivitas tes yang dilakukan. Teknik pengumpulan data yang digunakan dalam penelitian ini adalah: 1) Observasi, 2) Tes tulis hasil belajar, dan 3) angket. pengamatan. Hasil belajar meliputi aspek pengetahuan, aspek afektif dan psikomotorik siswa secara individual dan klasikal dengan menggunakan skor rata-rata. Tes tujuan produk yang digunakan meliputi tes awal dan tes akhir sedangkan tujuan psikomotorik dan afektif dinilai selama pembelajaran berlangsung. Analisis data yang digunakan dalam penelitian ini meliputi: 1) analisis validitas bahan ajar, 2) analisis 
Vol. 1 No. 2 September 2021 e-ISSN : 2797-3344 P-ISSN : 2797-3336

keterbacaan bahan ajar LKS, 3) analisis aktivitas siswa, 4) realibilitas aktivitas siswa, 5) analisis data angket respon siswa terhadap bahan ajar dan kegiatan pembelajaran. dan 6) analisis tes hasil belajar siswa aspek kognitif, afektif dan psikomotorik. Untuk mengukur tingkat ketercapaian hasil belajar dilakukan analisis hasil belajar berdasarkan data hasil belajar pretest dan postest tes kognitif, hasil pengamatan afektif dan psikomotorik.

\section{HASIL DAN PEMBAHASAN}

\section{Hasil Penelitian}

A. Hasil Pengembangan Bahan Ajar LKS

LKS yang dikembangkan dalam penelitian ini memiliki kerangka; Judul, Ringkasan Materi, Tujuan, Alat Bahan, Rumusan Masalah, Hipotesis, Persiapan Eksperimen, Langka Kegiatan, Hasil Pengamatan, Tugas dan Analisis. Terdapat 3 LKS yang telah dikemabngkan tentang lensa yaitu; 1) Sifat Lensa Cembung, 2) Sifat lensa cekung, dan 3) Pemanfaatan Lensa pada Penderita Miopi. Progres pengembangan dapat dilihat pada Gambar 1 berikut ini:

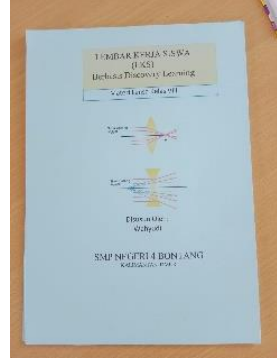

(a)

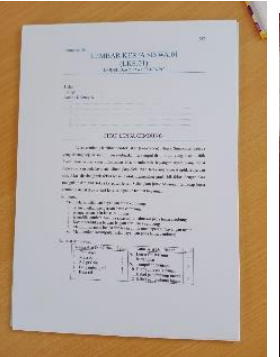

(b)

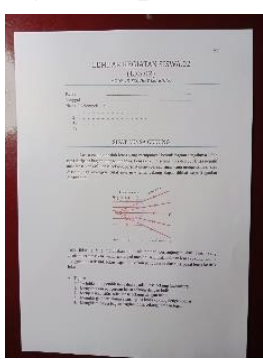

(c)

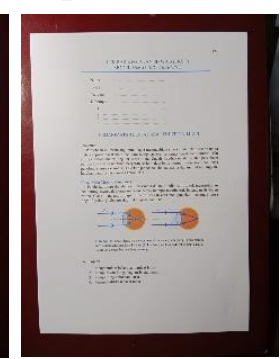

(d)

\section{Gambar 1: a) Cover LKS, b) LKS ke-1, c) LKS ke -2, d) LKS ke-3}

Hasil kevalitan, kepraktisan dan kefektifan bahan ajar LKS model discovery learning untuk meningkatkan hasil belajar pada materi lensa dengan cara; berdasarkan terori dan pendapat pakar, divalidasi oleh pakar, ujicoba-1 dan ujicoba-2 pada tiga kelas replikasi SMP negeri 4 Bontang yang homogen, yaitu kelas 8b, 8d, dan 8e. Bahan ajar yang dikembangkan yaitu lembar kegiatan siswa (LKS). Rincian hasil pengembangan LKS sebagai berikut:

1. Hasil validasi bahan ajar LKS yang di kembangkan peneliti kemudian di validasi oleh dua orang pakar, hasil validasi kelayakan LKS sebagai berikut:

a) Aspek penyajian didapatkan rerata 3,34 point artinya memiliki kevalittan yang tinggi.

b) Aspek bahasa dan keterbacaan didapatkan rerata 3,47 artinya memiliki kevalitan yang tinggi.

c) Aspek kesesuaian dengan pembelajaran discovery learning didapatkan rerata 3,47 artinya memiliki kevalitan yang tinggi.

2. Hasil validasi instrumen tes pengetahuan digunakan untuk pengumpul data berupa soal pilihan ganda sebanyak 30 soal. Tes digunakan untuk memperoleh informasi tentang hasil belajar kognitif siswa pada bahan kajian lensa yang meliputi preetest dan postest. Soal tes yang di kembangkan peneliti kemudian di validasi oleh dua orang pakar, hasil validasi kelayakan soal tes sebagai berikut:

a. Hasil terhadap Validasi Isi menperoleh nilai rerata skor 3,68 artinya baik

b. Hasil terhadap Validasi Bahasa memperoleh skor rerata 3,75 artinya baik.

B. Hasil Uji Coba-1 Bahan Ajar LKS

Hasil uji coba-1 penerapan bahan ajar LKS dilakukan di kelas terhadap 15 siswa oleh peneliti yang juga berperan sebagai guru di dapatkan data sebagai berikut:

1. Hasil analisis reliabilitas instrumen pengamatan aktivitas siswa oleh dua orang pengamat. Pengamatan dilakukan selama 3 kali pertemuan. Didapatkan hasil rerata nilai sebesar $83,20 \%$.

2. Hasil analisis respon siswa terhadap komponen LKS berdasarkan sembilan pertanyaan dalam angket didapatkan rerata poin gabungan sangat positif dan positif sebesar $83 \%$. 
Vol. 1 No. 2 September 2021 e-ISSN : 2797-3344 P-ISSN : 2797-3336

3. Hasil Analisis Ketercapaian Hasil Belajar Siswa:

a) Analisis aspek pengetahuan sebagai berikut;

1) Pretest ketuntasan $44,87 \%$.

2) Postest ketuntasan $82,87 \%$.

$\mathrm{N}$-Gain dari pretest dan postest 0,68

b) Analisis sensivitas 30 butir soal kognitif mendapatkan hasil 0,45 artinya lebih besar dari 0,3, ini menunjukkan soal sensitif

c) Analisis hasil belajar aspek afektif selama 3 replikasi yang meliputi $\mathrm{A} 1=$ Receiving, $\mathrm{A} 2=$ responding, $\mathrm{A} 3=$ valuing, $\mathrm{A} 4=$ Organizing, $\mathrm{A} 5=$ Characterizing by a value complex diperoleh nilai klasikal rerata 90,15

d) Analisis hasil belajar aspek psikomotorik selama 3 replikasi yang meliputi aspek $\mathrm{P} 1=$ Imitation, $\mathrm{P} 2=$ Manipulation, $\mathrm{P} 3=$ Precision, dan $\mathrm{P} 4=$ Articulation. Sehingga didapatkan rerata hasil 83,87.

4. Hasil penilaian akhir evaluasi pembelajaran berdasarkan gabungan ketiga ranah dengan proporsi $50 \%$ kognitif, $30 \%$ afektif dan $20 \%$ psikomotorik. Seperti pada table berikut ini:

Table 1: Nilai Akhir Evaluasi 50\% Kognitif, 30\% Afektif dan 20\% Psikomotorik

\begin{tabular}{|c|c|c|c|c|c|}
\hline \multirow{2}{*}{$\begin{array}{c}\text { No } \\
\text { Urut } \\
\text { Siswa }\end{array}$} & \multirow{2}{*}{$\begin{array}{c}\text { Aspek } \\
\text { Penilaian }\end{array}$} & \multicolumn{4}{|c|}{ REKAPITULASI NILAI } \\
\hline & & Kognitif & Afektif & Psikomotorik & Nilai Gabungan \\
\hline $1-32$ & Rerata Nilai & 77,00 & 90,00 & 84,00 & 82,00 \\
\hline
\end{tabular}

C. Hasil Uji Coba-2 Replikasi 1, 2, dan 3.

Hasil uji coba-2 penerapan bahan ajar LKS dilakukan di tiga kelas replikasi yang homogen, masing-masing 32 di dapatkan data sebagai berikut:

1. Hasil analisis reliabilitas instrumen pengamatan aktivitas siswa oleh dua orang pengamat. Pengamatan dilakukan pada replikasi 1, 2, dan 3. Didapatkan hasil rerata nilai sebesar $90,96 \%$.

2. Hasil analisis respon siswa pada replikasi 1, 2, dan 3, terhadap komponen LKS berdasarkan sembilan pertanyaan dalam angket didapatkan rerata poin gabungan sangat positif dan positif sebesar $95,30 \%$.

3. Hasil Analisis Ketercapaian Hasil Belajar Siswa

a) Analisis ketuntasan dan N-Gain aspek pengetahuan sebagai berikut;

1) Pretest meraih ketuntasan $53 \%$.

2) Postest meraih ketuntasan $80 \%$.

$\mathrm{N}-$ Gain dari pretest dan postest 0,75

b) Analisis sensivitas 30 butir soal kognitif pada 3 kelas replika mendapatkan hasil 0,57.

c) Analisis hasil belajar aspek afektif selama replikasi 1, 2, dan 3 yang meliputi A1 = Receiving, A $2=$ responding, $\mathrm{A} 3=$ valuing, $\mathrm{A} 4=$ Organizing, $\mathrm{A} 5=$ Characterizing by a value complex diperoleh nilai klasikal rerata 89.

d) Analisis hasil belajar aspek psikomotorik selama replikasi 1, 2, dan 3 yang meliputi aspek $\mathrm{P} 1=$ Imitation, $\mathrm{P} 2=$ Manipulation, $\mathrm{P} 3=$ Precision, dan $\mathrm{P} 4=$ Articulation. Sehingga didapatkan rerata hasil 86,67.

4. Hasil penilaian akhir evaluasi pembelajaran berdasarkan gabungan ketiga ranah dengan proporsi $50 \%$ kognitif, $30 \%$ afektif dan $20 \%$ psikomotorik. Seperti pada table berikut ini:

Table 2: Nilai Akhir Evaluasi 50\% Kognitif, 30\% Afektif dan 20\% Psikomotorik

No Aspek REKAPITULASI NILAI


Vol. 1 No. 2 September 2021 e-ISSN : 2797-3344 P-ISSN : 2797-3336

\begin{tabular}{cccccc}
\hline $\begin{array}{c}\text { Urut } \\
\text { Siswa }\end{array}$ & Penilaian & Kognitif & Afektif & Psikomotorik & Nilai Gabungan \\
\hline $\mathbf{1 - 3 2}$ & Rerata & 81,67 & 89,27 & 86,67 & 85,87 \\
\hline
\end{tabular}

\section{Pembahasan}

Hasil pengolahan data penelitian ujicoba I dan ujicoba II terhadap bahan ajar LKS model discovery learning dapat digunakan sebagai acuan untuk mendeskripsikan bahan ajar LKS yang dikembangkan. Begitu juga dapat digunakan untuk menjawab rumusan masalah penelitian yang meliputi: kevalidtan LKS, kepraktisan, dan keefektifan LKS berbasis pembelajaran model discovery learning untuk meningkatkan hasil belajar materi lensa siswa SMP Negeri 4 Bontang.

A. Pembahasan Hasil Validasi Pengembangan Bahan Ajar LKS

Lembar Kegiatan Siswa (LKS) yang telah dikembangkan oleh peneliti yang berorentasi pada model belajar discovery learning. LKS ini merupakan panduan siswa di dalam melakukan melakukan aktivitas penyelidikan dalam kegiatan pembelajaran yang berorentasi discovery learning. Siswa akan mendapatkan panduan untuk melakukan penemuan tujuan yang telah di tentukan oleh guru dengan LKS yang dibagikan. Hal ini sejalan dengan pendapat Prastowo (2014), bahwa LKS sebagai alat bantu belajar dari guru. Begitu sejalan dengan penemuan dalam penelitian yang telah dilakukan oleh Perdana (2017), LKS berbasis discovery learning layak dijadikan sebagai sumber pembelajaran fisika.

LKS yang telah dikembangkan peneliti kemudian ditelaah dan divalidasi oleh dua pakar di bidang fisika dan pendidikan fisika. Hasil penilaian oleh validator menunjukkan bahwa LKS yang dikembangkan memiliki skor rata-rata sebesar 3,40 dengan reliabilitas penilaian antara validator 1 dan validator 2 sebesar 95,74\%.

Berdasarkan hasil validasi pakar diperoleh informasi bahwa LKS yang telah dikembangkan peneliti memiliki kualitas dengan kategori baik untuk seluruh aspek penilaian (format, isi dan bahasa), sehingga dapat digunakan dalam pembelajaran fisika dengan sedikit revisi. Pencapaian kualitas ini dikarenakan telah melalui beberapa tahapan, yaitu analisis kebutuhan, analisis siswa, analisis konsep, analisis tugas, dan telaah dari pembimbing. Berdasarkan masukan dari validator, maka revisi yang telah dilakukan pada LKS ini adalah. 1) Menambahkan kunci pada LKS, 2) rincian dan urutan kegiatan yang jelas.

Berdasarkan pemaparan di atas maka LKS yang telah dikembangkan dan direvisi ini dapat digunakan sebagai panduan melakukan kegiatan oleh siswa di kelas pada uji coba I dan ujicoba II dengan tiga kelas replikasi.

B. Pembahasan Validasi Instrumen Tes Hasil Belajar

Instrumen tes hasil belajar merupakan alat evaluasi untuk mengukur kemampuan kognitif siswa. Penilaian hasil belajar dikembangkan peneliti dalam bentuk soal pilihan ganda sejumlah 30 soal. Taksonomi aspek kognitif yang dikembangkan dalam tes soal mengacu pada taksonomi yang dikembangkan oleh Bloom, yaitu ranah $\mathrm{C} 1$ (mengingat), $\mathrm{C} 2$ (memahami), C3(menerapkan, C4(menganalisis), C5(mensintesis), C6(mengevaluasi).

Sebuah instrumen tes yang akan digunakan untuk evaluasi harus memiliki karakteristik valid (Sukardi. 2010). Jenis validitas yang dipakai disini adalah validitas isi dan bahas yang tidak memerlukan pengujian statistika (Sudjana. 2013). Valid artinya ketepatan interprestasi yang dihasilkan dari skor tes atau instrumen evaluasi.

Hasil validasi instrumen tes hasil belajar aspek pengetahuan diperoleh rata-rata validitas isi sebesar 3,68. Serta validitas bahasa dan penulisan soal memperoleh skor 3,75. Reliabilitas penilaian antara validator 1 dan validator 2 pada validitas isi sebesar 94,76\%, sedangkan pada bahasa dan penulisan soal sebesar 91,90\%. Dengan demikian, instrumen penilaian hasil belajar yang dikembangkan berkategori valid (baik) dan reliabel, sehingga layak digunakan sebagai alat ukur hasil belajar aspek pengetahuan siswa.

C. Pembahasan Hasil Kepraktisan Bahan Ajar Model discovery learning untuk Meningkatkan Hasil Belajar Materi Lensa Siswa SMP Negeri 4 Bontang 


\section{Vol. 1 No. 2 September 2021 e-ISSN : 2797-3344 P-ISSN : 2797-3336}

Kepraktisan bahan ajar LKS model discovery learning untuk untuk meningkatkan hasil belajar materi lensa SMP Negeri 4 Bontang yang dikembangkan meliputi: keterlaksanaan LKS, dan aktivitas siswa. selama proses pembelajaran dapat dipaparkan sebagai berikut.

Selama pelaksanaan pembelajaran guru mengelola pembelajaran sesuai dengan tahapan-tahapan model discovery learning. Guru mampu menggiring siswa ke dalam situasi discovery learning, sehingga siswa dapat menemukan sendiri konsep materi lensa melalui penemuan dengan benar. Hal ini sesuai dengan teori Scaffolding Vygotsky tentang konsep pembelajaran dengan bantuan, yang menyatakan bahwa guru seharusnya memandu proses pembelajaran, sehingga siswa dapat menguasai secara tuntas keterampilan-keterampilan dengan fungsi kognitif yang lebih tinggi (Jahja.2015).

D. Pembahasan Hasil Pengamatan Aktivitas Siswa

Aktivitas siswa diamati selama kegiatan pembelajaran berlangsung menggunakan lembar pengamatan aktivitas siswa. Hasil observasi terhadap aktivitas siswa selama selama proses pembelajaran dengan menggunakan model discovery learning untuk meningkatkan hasil belajar siswa pada materi lensa didapatkan nilai pada ujicoba 1 sebesar 83,20\% dan ujicoba II sebesar 90,96\%, ini menunjukkan LKS yang telah dikembangkan memiliki kemampuan untuk mengkondisikan siswa sangat aktif dan terarah.

Keterlibatan aktif dan terarah oleh siswa dengan pembelajaran discovery learning ini meliputi membaca bahan ajar, menuliskan masalah, merumuskan hipotesis, melaksanakan percobaan, mempresentasikan hasil percobaan, membuat kesimpulan, bertanya dan menanggapi pertanyaan teman/kelompok/guru. Sementara itu, aktivitas yang berupa mendengarkan penjelasan guru serta berperilaku tidak relevan tidak menunjukkan keterlibatan aktif siswa selama KBM.

Berdasarkan ujicoba 1 diketahui bahwa pada aktivitas; mendengarkan penjelasan guru $6,67 \%$, membaca bahan ajar 6,54\%, menuliskan rumusan masalah 6,15\%, merumuskan hipotesis $6,38 \%$, bertanya kepada guru $6,96 \%$, melaksanakan percobaan (memilih alat, menyusun, melakukan pengamatan, mencatat hasil pengamatan) $23,55 \%$, melakukan diskusi dengan kelompok dalam mengerjakan LKS 12,39\%, mempresentasikan hasil percobaan $24,33 \%$, membuat kesimpulan 6,51\%, prilaku tidak relevan (melakukan percakapan dan tindakan yang tidak relevan dengan kegiatan belajar) $0,52 \%$.

Aktivitas ke 6, ujicoba 1 yaitu melaksanakan percobaan (memilih alat, menyusun, melakukan pengamatan, mencatat hasil pengamatan) mendapatkan rata-rata nilai tinggi yakni $17,81 \%$, begitu juga pada ujicoba II pada replikasi I, II, dan III secara beturut-turut mendapatkan $23,55 \%, 23,08 \%$, dan $26,37 \%$ artinya pada pembelajaran dengan menggunakan model discovery learning bisa mendorong siswa lebih aktif. Hal ini akan mengkondisikan siswa dapat menemukan konsep-konsep dan prinsip-prinsip melalui proses mentalnya sendiri. Proses mental yang dimaksud adalah mengamati, mencerna, mengerti, menggolong-golongkan, membuat dugaan, menjelaskan, mengukur, membuat kesimpulan (Cahyo, 2012).

Aktivitas melakukan diskusi dengan kelompok dalam mengerjakan LKS, dengan persentase $17,17 \%$ pada uji coba I, hal ini menunjukkan bahwa siswa dalam kegiatan pembelajaran berada di lingkungan sosial yang baik, mereka terus menerus belajar melalui interaksi dengan orang lain di sekitar mereka. Aktivitas presentase hasil percobaan di dalam ujicoba II pada replikasi I, II, dan III mendapatkan persentase yang lebih tinggi dari yang lainya yaitu $24,33 \%, 23,31 \%$, dan $24,90 \%$ hal ini menunjukkan pula pembelajaran dengan menggunakan model Discovery Learning merupakan pembelajaran dengan pengalaman langsung yaitu dengan melakukan langsung (Dale dalam Sudjana, 2013)

Aktivitas mendengarkan penjelasan guru pada ujicoba I dengan rata-rata persentasenya $7 \%$, sedangkan pada ujicoba II yaitu $6,67 \%, 8,16 \%$, dan $6,25 \%$ dan aktivitas bertanya kepada guru persentasenya $13,78 \%$, dan tidak mengalami perubahan persentase secara signifikan pada ujicoba II yaitu $6,96 \%, 6,72 \%$, dan 3,71\%, menunjukkan bahwa, dalam pembelajaran discovery learning guru masih berperan dalam kegiatan pembelajaran namun sangat sedikit, siswa cenderung mandiri. Pembukaan pembelajaran guru memulai kegiatan PBM dengan 
mengajukan pertanyaan, anjuran membaca buku, dan aktivitas belajar lainnya yang mengarah pada persiapan pemecahan masalah. Stimulasi pada tahap ini berfungsi untuk menyediakan kondisi interaksi belajar yang dapat mengembangkan dan membantu siswa dalam mengeksplorasi bahan. Memberikan stimulation bisa menggunakan teknik bertanya yaitu dengan mengajukan pertanyaan-pertanyaan yang dapat menghadapkan siswa pada kondisi internal yang mendorong eksplorasi. Seorang guru harus menguasai teknik-teknik dalam memberi stimulus kepada siswa agar tujuan mengaktifkan siswa untuk mengeksplorasi dapat tercapai.

Data tersebut menunjukkan bahwa dalam kegiatan pembelajaran siswa sangat berperan aktif melalui membaca bahan ajar, merumuskan masalah, merumuskan hipotesis, mengidentifikasi variabel, melaksanakan percobaan, mempresentasikan hasil percobaan, bertanya dan menanggapi pertanyaan teman/kelompok/guru. Dalam pembelajaran guru lebih berperan sebagai fasilitator yang membimbing dan mengarahkan siswa dalam belajar. Dengan demikian, siswa tidak hanya belajar dari apa yang disampaikan oleh guru, tetapi juga belajar dari aktivitas yang memungkinkan siswa dapat membangun sendiri pengetahuannya.

Berdasarkan analisis aktivitas siswa di atas, maka dapat diperoleh gambaran bahwa siswa telah melakukan aktivitas dominan selama melakukan proses belajar dengan discovery learning.

E. Pembahasan tentang Keefektivan Perangkat Pembelajaran Model Discovery Learning untuk Meningkatkan Hasil Belajar Materi Lensa Siswa SMP Negeri 4 Bontang

1. Hasil Analisis Respon

Data respon siswa terhadap komponen-komponen kegiatan pembelajaran lensa dengan model discovery learning untuk meningkatkan hasil belajar siswa dikumpulkan melalui angket. Beberapa uraian pertanyaan-pertanyaan bagaimana pendapat siswa terhadap isi materi pelajaran, LKS, suasana, dan cara mengajar guru; Kelas replikasi I didapatkan 98\% merasa tertarik dan $2 \%$ tidak tertarik, $96 \%$ merasa baru dan $4 \%$ tidak baru, $93 \%$ merasa mudah dan $7 \%$ tidak mudah. Kelas replikasi II didapatkan $97,50 \%$ tertarik dan 2,50\% tidak tertarik, $96 \%$ baru dan $4 \%$ tidak baru, $99 \%$ merasa mudah dan $1 \%$ tidak mudah. Kelas replikasi III didapatkan 99\% merasa tertarik dan 1 tidak tertarik, 97\% merasa baru dan 3\% tidak baru, 98\% merasa mudah dan $2 \%$ tidak mudah. Hal ini menunjukkan pengunaan bahan ajar yang dikembangkan mendapatkan respon yang positif oleh siswa.

Pertanyaan mengenai minat dalam pembelajaran dengan model discovery learning; dari kelas replikasi I didapatkan $97 \%$ setuju dan $3 \%$ tidak setuju, dari kelas replikasi II didapatkan $100 \%$ setuju dan $0 \%$ tidak setuju, dari kelas replikasi III didapatkan $98 \%$ setuju dan $2 \%$ tidak setuju. Simpulan terhadap respon siswa bahwa model pengajaran discovery learning sangat diminati oleh siswa dalam proses belajar mengajar di kelas.

Pertanyaan mengenai kejelasan dalam kegiatan belajar mengajar oleh guru, dari kelas replikasi I didapatkan $94 \%$ merasa jelas dan $6 \%$ tidak jelas, kelas replikasi II didapatkan 100\% merasa jelas dan $0 \%$ tidak jelas, kelas replikasi III didapatkan $98 \%$ merasa jelas dan $2 \%$ tidak jelas. Berdasarkan data di atas model pembelajaran discovery learning yang digunakan untuk melakukan penelitian di kelas dapat dijalankan oleh guru dengan baik.

Pertanyaan tentang respon terhadap ketrampilan proses; kelas replikasi I memberikan respon $87 \%$ merasa tertarik dan 3\% tidak tertarik. Kelas replikasi II memberikan rspon 100\% tertarik dan $0 \%$ tidak tertarik, kelas replikasi III memberikan respon $95 \%$ teratrik dan $5 \%$ tidak tertarik. Hal ini menunjukkan siswa mempunyai respon positif dengan kegiatan ilmiah.

Pertanyan tentang kemudahan menjawan soal, kelas replikasi I memberikan $78 \%$ merasa mudah dan $22 \%$ tidak mudah, kelas replikasi II memberikan respon $94 \%$ mudah dan $6 \%$ tidak mudah, kelas replikasi III memberikan respon $94 \%$ mudah dan $6 \%$ tidak mudah. Hal ini menunjukkan dengan model pembelajaran discovery learning membuat siswa tertarik untuk belajar lensa

Beberapa siswa yang menjawab tidak mudah adalah pada menjawab soal. Hal ini terjadi dikarenakan pembelajaran pada model discovery learning lebih terfokus pada penemuan 
konsep, untuk lebih mampu dalam pemecahan soal siswa bisa mengembangkan sendiri di luar jam pelajaran dengan konsep yang sudah dimilikinya.

Sebagian besar siswa memberikan respon positif terhadap ketertarikan, keterbaharuan dan kemudahan dalam memahami komponen pembelajaran. Respon tersebut menunjukkan bahwa siswa dapat menerima dengan baik bahan ajar bahan ajar LKS, materi pembelajaran, suasana belajar dan cara guru mengajar. Hal tersebut menunjukkan bahwa setiap pertemuan, siswa menggunakan LKS sebagai dasar pencarian informasi-informasi untuk menyelesaikan tugas, masalah, dan pertanyaan-pertanyaan percobaan, serta eksperimen.

Pembelajaran ini menyajikan beberapa kegiatan yang dapat memancing siswa untuk menyelesaikannya, diantaranya: (1) menjawab pertanyaan, (2) mengambarkan bayangan benda oleh lensa, (3) mengamati bentuk bayangan, (4) pertanyaan-pertanyaan yang mengarahkan siswa menemukan konsep, dan (5) percobaan, membuat menemukan bayangan benda. Kegiatan-kegiatan tersebut bertujuan agar siswa merasa tertantang, baru dan menarik maka dalam proses pembelajaran. Masalah yang diberikan kepada siswa membuat mereka merasa tertantang, baru dan menarik maka dalam proses pembelajarannya siswa akan mengerahkan seluruh upaya untuk menyelesaikan masalah tersebut baik secara individual maupun kelompok dan dapat memicu motivasi interistik pada siswa.

Sebagian besar siswa memberikan respon positif terhadap proses pembelajaran, hal tersebut berarti siswa tertarik apabila pembelajaran dengan model discovery learning diterapkan dalam pembelajaran lensa selanjutnya dan pada mata pelajaran selain lensa yang karakteristiknya sama. Ketertarikan tersebut diharapkan dapat mendorong, menginspirasi, dan membiasakan siswa menggunakan aktivitas eksperimen atau terbiasa menanggapi serta menyelesaikan masalah sehari-hari seperti yang ditempuh pada ilmuwan (scientist).

F. Pembahasan Hasil belajar Siswa

1. Kognitif (pengetahuan)

Aspek pengetahuan merupakan hasil belajar yang perlu dinilai di dalam setiap pembelajaran. Taksonomi tujuan-tujuan pendidikan yang dikembangkan oleh Bloom, aspek pengetahuan ini dibagi menjadi beberapa jenjang, yaitu pengenalan, pemahaman, aplikasi, analisis, sintesis, dan evaluasi. Evaluasi akhir pengajaran terhadap tercapainya tujuan-tujuan aspek pengetahuan (knowledge) perlu dilakukan secara terpisah di samping evaluasi terhadap prilaku yang lain. Evaluasi aspek pengenalan caranya dengan memberikan pertanyaanpertanyaan bentuk pilihan berganda yang menuntut siswa agar melakukan identifikasi tentang fakta, definisi, dan contoh-contoh yang benar. Teknik aspek mengingat kembali (recall) caranya dengan pertanyaan-pertanyaan terbuka-tertutup berlangsung untuk mengungkapkan jawaban-jawaban yang benar. Teknik evaluasi aspek pemahaman caranya mengajukan pertanyaan-pertanyaan yang menuntut identifikasi terhadap pertanyan-pertanyaan benar-salah, kesimpulan, klarifikasi, dengan daftar pertanyaan yang menjodohkan yang berkenaan dengan konsep (Hamalik, 2010)

Hasil belajar siswa meliputi hasil belajar kognitif, afektif, dan psikomotorik. Sebelum dimulai pelajaran diadakan pretest terhadap kemampuan kognitif siswa pada materi lensa. Hasil pretest digunakan untuk mengetahui kemampuan awal siswa sehingga dapat menentukan metode mengajar selanjutnya. Pasca proses belajar mengajar materi lensa diadakan postest. Hasil tes postest digunakan untuk mengetahui ketercapaian indikator pembelajaran berbasis menggunakan model discovery learning. Soal tes sebanyak 30 soal pilihan ganda materi lensa. Soal postest sama dengan soal pretest tanpa pemberitahuan kepada sebelumnya.

Berdasarkan hasil prestest dan postest kognitif digunakan untuk menganalisis ketuntasan, sensitifitas dan $\mathrm{N}$-Gain aspek pengetahuan butir soal. Hasil dari kelas replikasi I menunjukkan angka sebesar rerata pretest $29,19 \%$, rerata postest $80,78 \%$, N-Gain 0,73 , dan sensitifitas 0,52. Hasil dari kelas dari replikasi II menunjukkan angka sebesar rerata pretest $19,06 \%$, postest $84,19 \%$, N-Gain 0,80 , dan sesitifitas 0,66 . Hasil dari kelas replikasi III menunjukkan angka sebesar rerata pretest $29,22 \%$, postest $80,03 \%$, N-Gain 0,72 , dan sesitifitas 0,54. artinya bahwa butir soal yang diujikan peka terhadap efek-efek pembelajaran lensa 
berbasis model discovery learning untuk meningkatkan hasil belajar. Ketuntasan rata-rata materi lensa dari hasil ketiga kelas replikasi pada pretest sebesar $0 \%$ dan pada postest sebesar $81,27 \%$, dan $18,73 \%$ siswa yang tidak tuntas akan diberikan soal yang bobotnya sama dengan sedikit berubah dari sisi redaksi soalnya.

Ketercapaian indikator pembelajaran $100 \%$ tercapai pada ujicoba II namun nilainya secara rata-rata klasikal menurun dari ujicoba I. Indikator ketercapaian pembelajaran pada ujicoba I ada yang tidak tuntas yaitu indikator nomor 9 yang berbunyi," memilih susunan jalannya sinar pada lensa cekung dengan benar". Sedangkan soal yang dipakai untuk mengevaluasi ketuntasan indikator nomor 9 adalah soal nomor 17. Kesensitifan soal nomor 17 sebesar 0,33 artinya soal mempunyai kategori sensitif. Soal nomor 17 dapat dipakai untuk membedakan kemampuan siswa sebelum dan sesudah mengikuti pembelajaran discovery learning. Dapat diperkirakan untuk soal nomor 17 ini siswa yang bersangkutan belum bisa menggunakan pengetahuan yang sudah difahami.

Solusi yang memungkinkan untuk diterapkan dalam rangka mencapai ketuntasan tujuan pembelajaran pengetahuan adalah dengan mengubah soal yang berkaitan dengan tujuan pembelajaran tersebut dengan bobot yang sama tetapi redaksi bahasa yang mudah difahami.

Perolehan nilai pretest yang digunakan untuk mengetahui kemampuan awal siswa terhadap materi lensa dan nilai postest yang digunakan untuk mengetahui kemampuan siswa setelah mengikuti pembelajaran. Hasil dari penelitian ini yang dianalisis menggunakan analisis Normalized-Gain menunjukkan bahwa siswa yang mengalami peningkatan hasil belajar dan masuk dalam kriteria tinggi sebesar 82,87\% dan kategori sedang sebesar 17,13\% (Hake, 1999). Peningkatan yang ditunjukkan oleh hasil analisis dengan menggunakan $N$-Gain ini menunjukkan tentang penerapan dari pengembangan bahan ajar LKS berbasis model discovery learning efektif dalam meningkatkan penguasaan aspek pengetahuan pada materi lensa.

Analisis mengenai sensitivitas butir soal aspek pengetahuan pada uji coba I, sensitivitas butir soal digunakan untuk mengetahui apakah soal yang dikembangkan baik atau tidak untuk membedakan kemampuan awal siswa dengan setelah mengikuti pembelajaran discovery learning, dapat dilihat dari tingkat sensitivitas tiap butir soal. Hasil analisis diperoleh bahwa tidak ada butir soal penguasaan pengetahuan yang dikembangkan mendapat nilai di bawah 0.30 maka soal yang mempunyai sensitiifitas baik adalah 30 soal (Gronlund dan Linn, 1995).

2. Afektif (sikap)

Ranah afektif adalah ranah yang berkaitan dengan sikap dan nilai. Sikap seseorang terhadap sesuatu bisa dipengaruhi dari pengetahuan yang dimilikinya terhadap sesuatu itu. ranah afektif mencangkup watak prilaku seperti perasaan, minat sikap emosi, atau nilai, ketiga hal tersebut merupakan karakteristik manusia sebagai hasil belajar dalam bidang pendidikan(Kusnandar, 2013).

Penilaian sikap kopetensi sikap adalah penilaian yang dilakukan oleh guru untuk mengukur tingkat pencapaian kopetensi sikap siswa yang meliputi aspek penerimaan, respon penilaian, organisasi, pembentukan karakter dengan nilai yang komplek. Dalam penelitian ini penilaian sikap mengunakan hasil pengamatan oleh dua orang pengamat. Data hasil pengamatan digunakan untuk mengukur ketercapaian siswa dalam belar di kelas.

Rekapitulasi hasil belajar aspek afektif siswa seluruhnya tuntas dan mengalami peningkatan dari hari pertama sampai hari ketiga. Hari pertama 85,67 \%, hari kedua 90,56\%, dan hari ketiga 94,22\%. Artinya kemampuan umum seperti penerimaan(receiving), respon(responding), penilaian(valuing), organisasi (organizing), pembentukan karakter dengan nilai yang komplek(characterizing by a value complex) telah terinternalisasi pada siswa dengan sangat baik.

Aspek penerimaan (receiving) adalah kesadaran atau sensitifitas adanya ide-ide tertentu, bahan, atau fenomena merupakan tingkatan aspek terendah dari afektif. Aspek tanggapan(responding) merujuk kepada tingkatan yang lebih tinggi berupa partisipasi aktif dari siswa dalam menerima disertai dengan reaksi tertentu. Penilaian(valuing) berkaiatan dengan nilai yang melekat pada siswa tentang obyek tertentu, fenomena atau prilaku yang berimplikasi 
pada tingkat penerimaan dan komitmen. Organisasi(organizing) merujuk pada upaya menyatukan nilai yang berbeda, menyelesaikan konflik, dan membangun sistem nilai internal yang konsisten, pembentukan karakter dengan nilai yang komplek(characterizing by a value complex) merupakan tingkat yang paling tinggi dari aspek afektif ditandai dengan penilaian kompleks, sistem nilai peserta siswa mengontrol prilaku dalam waktu yang cukup lama guna membentuk gaya hidup atau karakter (Yaumi,2013).

Winkel (2014), menerangkan bahwa aspek afektif meliputi a) penerimaan(receiving) yaitu kepekaan akan adanya suatu perangsang dan untuk memperhatikan adanya rangsangan itu, seperti buku pelajaran atau penjelasan oleh guru. Contoh memandangi gambar dalam buku atau LKS, mendengarkan apa yang disampaikan oleh guru. b) respon(responding) yaitu kerelaan memperhatikan secara aktif dan berpartisipasi dalam suatu kegiatan. Kesediaan itu dinyatakan dalam memberikan reaksi terhadap rangsangan yang disajikanatau menunjukkan minat. Misal; dengan membawa pulang buku bacaan yang ditawarkan kepadanya. c) penilaian/penetuan(valuing) sikap yaitu kemauan untuk memberikan nilai terhadap sesuatuyang membawa diri sesuai dengan penilaian itu. d) mulai membentuk suatu sikap menerima menolak atau mengabaikan. Sikap itu dinyatakan dalam tingkah laku yang sesuai dan konsisten dengan sikap batin. e) organisasi(organizing) yaitu mencakup kemampuan untuk membentuk suatu sistem nilai sebgai pedoman dan pegangandalam kehidupan. f) Pembentukankarakter dengan nilai yang komplek(characterizing by a value complex) yaitu kemampuan untuk menghayati nilai-nilai kehidupan. misalnya mensyukuri nikmat diberikannya lensa mata yang bagus oleh Allah.

3. Psikomotorik

Ranah psikomotorik adalah ranah yang berkaitan dengan ketrampilan (skill) atau kemampuan bertindak setelah seseorang menerima pengalaman belajar tertentu. Psikomotorik berhubungan dengan hasil belajar yang pencapaiannya berhubungan dengan kopentensi pengetahuan. Artinya kopetensi ketrampilan merupakan implikasi dari kopetensi pengetahuan. Ketrampilan itu sendiri menunjukkan kualitas ketrampilan seseorang dalam suatu tugas(Kusnandar, 2013).

Penilaian kopetensi ketrampilan (psikomotorik) merupakan penilaian yang dilakukan guru untuk mengukur tingkat pencapaian kompetensi ketrampilan peserta didik yang meliputi aspek imitasi, manipulasi, presisi, artikulasi, dan naturalisasi(Kusnandar, 2013). Penilaian dalam penelitian ini menggunakan pengamatan pada saat siswa melakukan percobaan mengenai lensa di laboratorium IPA, dari situ didapatkan hasil pengamatan dan dijadikan bahan untuk menilai ketrampilan siswa. hal ini sejalan dengan hasil penelitian yang dilakukan oleh Qhotimah (2018), bahwa LKS dapat digunakan sebagai bahan ajar pendukung dalam pembelajaran.

Kemampuan aspek psikomotorik siswa dalam mengikuti pembelajaran di kelas mengalami peningkatan dari pertemuan pertama nilai rata-rata kelas $75 \%$ menjadi $85 \%$ pada pertemuan kedua dan rata-rata $90 \%$ pada pertemuan ketiga. Artinya kemampuan aspek menirukan (Imitation), Manipulasi (manipulation), presisi (precision), dan artikulasi (articulation) telah bagus dalam ketrampilan melakukan percobaan materi lensa. Nilai bagus ini dikarenakan di dalam pelaksanaan percobaan siswa didorong untuk secara cermat mengikuti petunjuk yang telah di berikan oleh guru, namun begitu apabila siswa mengalami kesulitan maka guru membimbing percobaan seperlunya saja. Kelemahan model discovery learning salah satunya adalah kurang mendapatkan perhatian dalam hal ketrampilan dan emosi secara keseluruhan (Kemendikbud, 2013).

Nilai akhir evaluasi hasil belajar merupakan akumulasi dari aspek kognitif, afektif dan psikomotorik. Semua siswa mendapat nilai tuntas sehingga tujuan pendidikan dalam hal ini telah tercapai. Pendidikan sebagai pengembangan kepribadian, akhlak mulia, pekerja yang terampil, dan pendidikan sebagai pengembang pribadi yang paripurna. UU Sisdiknas No. 20 Tahun 2003 menerangkan bahwa, tujuan pendidikan nasional adalah untuk mengembangkan potensi peserta didik agar menjadi manusia yang beriman dan bertaqwa kepada Tuhan yang 
Vol. 1 No. 2 September 2021 e-ISSN : 2797-3344 P-ISSN : 2797-3336

Maha Esa, beraklaq mulia, sehat, berilmu, cakap, kreatif, mandiri dan menjadi warga negara yang demokratis serta bertanggung jawab.

\section{KESIMPULAN}

Berdasarkan hasil analisis data dan pembahasan hasil penelitian, maka diperoleh beberapa temuan penelitian sebagai berikut:

1. Validitas bahan ajar LKS pembelajaran lensa berbasis model discovery learning untuk meningkatkan hasil belajar materi lensa SMP Negeri 4 Bontang berkategori valid sehingga layak digunakan dalam pembelajaran.

2. Kepraktisan bahan ajar LKS yang dikembangkan melalui ujicoba I dan II dilihat dari aktivitas siswa selama pembelajaran materi lensa berbasis model discovery learning untuk meningkatkan hasil belajar materi lensa SMP Negeri 4 Bontang menunjukkan pembelajaran berpusat pada siswa (student centered).

3. Keefektivan bahan ajar LKS yang dikembangkan melalui ujicoba I dan II dilihat dari:

a. Siswa menunjukkan respon yang positif terhadap pembelajaran lensa berbasis model discovery learning untuk meningkatkan hasil belajar materi lensa SMP Negeri 4 Bontang.

b. Penerapan bahan ajar berbasis model discovery learning mampu meningkatkan hasil belajar aspek pengetahuan, afektif dan psikomotorik pada materi lensa siswa SMP Negeri 4 Bontang

Berdasarkan temuan-temuan di atas maka dapat disimpulkan bahwa pengembangan bahan ajar LKS berbasis model discovery learning mampu untuk meningkatkan hasil belajar materi lensa siswa SMP Negeri 4 Bontang.

\section{DAFTAR PUSTAKA}

Alfitry. Shilfia. 2020. Model Discovery Learning dan Perbedaan Motivasi dalam Belajar. Dari https://www.google.co.id/books/edition/MODEL_DISCOVERY_LEARNING_DAN _PEMBERIAN_M/dmpMEAAAQBAJ?hl=id\&gbpv=1\&dq=metode+discovery+lear ning\&printsec $=$ frontcover

Cahyo. 2013. Panduan aplikasi teori-teori belajar mengajar teraktual dan terpopuler. Penerbit. Diva Press. Jogjakarta.

Damanyanti, S, D., Ngazizah, N. (2013). Pengembangan Lembar Kerja Siswa (LKS) dengan Pendekatan Inkuiri Terbimbing untuk Mengoptimalkan Kemampuan Berfikir Kritis Peserta Didik pada Materi Listrik Dinamis SMA Negeri 3 Purworejo Kelas X Tahun Pelajaran 2012/2013. Program Studi Pendidikan Fisika Universitas Muhammadiyah Puurworejo. Purworejo Jawa Tengah.

Gronlundn. E. and Linn, R.L.1995. Measurement and assesment in teaching (7th ed). New Jersey: Merril Englewood Cliffs.

Hake. 1999. Analyzing change/gain scores. (Online). Tersedia http://www. physicsindiana.edu/sdi/Analyzing-Change-Gain. pdf. Diakses 15 November 2013

Hamalik, Oemar. 2010. Psikologi belajar dan mengajar. Sinar Baru Algensindo. Bandung.

Jahja. Y,. 2015. Psikologi Perkembangan Edisi Pertama. Penerbit Prenadamedia Group. 2015. Jakarta.

Kementrian Pendidikan dan Kebudayaan, 2013. Modul pelatihan implementasi Kurikulum 2013. Jakarta.

Kemp, Morrison dan Ross 1994. Proses Perencanaan pengajaran. Penerbit ITB. Bandung.

Kusnandar. 2013. Penilaian Autentik (penilaian hasil belajar peserta didik berdasarkan kurikulum 2013). PT Raja Grafindo Persada, Jakarta

Lestari, Ika. 2013. Pengembangan bahan ajar berbasis kopetensi sesuai dengan kurikulum tingkat satuan pendidikan. Akademia Permata. Padang.

Prastowo. A. 2014. Panduan Kreatif Membuat Bahan Ajar Inovatif: Menciptakan Metode Pembelajaran yang Menarik dan Menyenangkan. Diva Press. Yogyakarta. 
Perdana.A., (2017). Siswyo, Sunaryo. Pengembangan Lembar Kerja Siswa Berbasis Discovery Learning Berbantuan Phet Interactive Simulations Pada Materi Hukum Newton. Jurnal Wahana Pendidikan Fisika (2017) Vol.2 No.1 73-79.

Qhotimah.C, Hakim,L., 2018. Pengembangan Lembar Kegiatan Peserta Didik (Lkpd) Sebagai Bahan Ajar Dengan Pendekatan Saintifik Pada Mata Pelajaran Produk Syariah Di Kelas Xi Kompetensi Keahlian Perbankan Syariah. Jurnal Pendidikan Akuntansi. Volume 06 Nomor 02 Tahun 2018

Sudjana, Nana, 2013. Dasar-Dasar Proses Belajar Mengajar. Penerbit Sinar Baru Algensindo. Bandung,

Sukardi. 2010. Evaluasi Pendidikan Prinsip \& Operasionalnya. Jakarta. Bumi Aksara.

Septantiningtyas. $\quad$ Niken, 2021. Pembelajaran Sains. https://www.google.co.id/books/edition/PEMBELAJARAN_SAINS/QcITEAAAQB $\mathrm{AJ} ? \mathrm{hl}=\mathrm{id} \& \mathrm{gbpv}=1 \& \mathrm{dq}=$ pembelajaran+sain \&printsec $=$ frontcover

Ulfah, A., Bintari,H,S., \& Pamelasari,D,S., (2013). Pengembangan LKS IPA Berbasis Word Square Model Keterpaduan Conected. Unnes Science Education Journal. Semarang.

UU Sisdiknas No. 20 Tahun 2003

Winkel, 2014. Psikologi pendidikan. Sketsa. Yogyakarta.

Yaumi, Muhammad. (2013). Prinsip-prinsp desain pembelajaran. Kencana Prenada Media Group. Jakarta. 